Abstracta Iranicacta Iranica

Revue bibliographique pour le domaine irano-aryen

Volume 32-33 | 2013

Comptes rendus des publications de 2009-2010

\title{
Ralph Kauz. Hofzeremoniell und Politik bei den Timuriden: Die Gesandtschaften aus China
}

\section{Colin P. Mitchell}

\section{(2) OpenEdition \\ 1 Journals}

\author{
Electronic version \\ URL: http://journals.openedition.org/abstractairanica/40606 \\ DOI: 10.4000/abstractairanica.40606 \\ ISSN: 1961-960X \\ Publisher: \\ CNRS (UMR 7528 Mondes iraniens et indiens), Éditions de l'IFRI \\ Printed version \\ Date of publication: 1 December 2013 \\ ISSN: 0240-8910

\section{Electronic reference} \\ Colin P. Mitchell, « Ralph Kauz. Hofzeremoniell und Politik bei den Timuriden: Die Gesandtschaften aus \\ China ", Abstracta Iranica [Online], Volume 32-33 | 2013, document 227, Online since 01 July 2016, \\ connection on 26 September 2020. URL : http://journals.openedition.org/abstractairanica/40606 ; \\ DOI : https://doi.org/10.4000/abstractairanica.40606
}

This text was automatically generated on 26 September 2020 .

Tous droits réservés 


\title{
Ralph Kauz. Hofzeremoniell und Politik bei den Timuriden: Die Gesandtschaften aus China
}

\author{
Colin P. Mitchell
}

\section{REFERENCES}

Ralph Kauz. « Hofzeremoniell und Politik bei den Timuriden: Die Gesandtschaften aus China », in : Ralph Kauz, Giorgio Rota, Jan Paul Niederkorn, eds., Diplomatisches Zeremoniell in Europa und im mitteleren osten in der frühen Neuzei. Vienna, Verlag der Österreichischen Akademie der Wissenschaften, 2009, p. 349-365.

1 Ralph Kauz laments the Western centric approach we as scholars have brought to the study of the Mongol and Timurid periods. For him, there is an entire narrative and framework to the east - China - which demands attention and inclusion in Mongol and Timurid studies. In an era when "global studies" are becoming ever more appealing, this kind of thinking could very well be applauded. Indeed, as David Morgan suggested in his seminal The Mongols (1987), we work under the restriction of language barriers, and there are very few crossovers of specialists between medieval Persian and Chinese. This has, in turn, shaped the field of Turco-Mongol history. We should encourage future generations of graduate students interested in this area to focus on the languages of primary sources so as to realign the current historiographical approach and better acknowledge the Eurasian aspects of the Mongol and post-Mongol eras.

What Kauz presents here is a fairly general, occasionally meandering, overview of the world of the Chinese during the Ming period and the fragmented politics of central Asia and Iran during the reigns of Timur (1370-1405) and his successors during the 15th century. One focus is the issue of "courtly diplomatic ceremony" at the Timurid court, and the description of the visit by the famous dignitary Roy Gonzalez de Clavijo (1403-1406) is juxtaposed with that of a Chinese emissary, Chen Cheng who came to 
Herat between 1413-15. In his quest to highlight the importance of protocol, Kauz also presents Ḥāfeẓ-e Abrū's description of a Chinese embassy to Šāh RoH̆'s court.

\section{AUTHORS}

\section{COLIN P. MITCHELL}

Dalhousie University, Canada 